\title{
Harmonizing European patent practice
}

Sir - The view of Howard Dalton et al. that the proposed European Directive on the Legal Protection of Biotechnological Inventions "poses a threat to the future of scientific and medical research" (Nature $385,672 ; 1997)$ is based on several misconceptions. The directive seeks to harmonize European patent practice in biotechnology; it does not add any new types of patent practice, nor does it broaden what is and what is not patentable in biotechnology.

Patents are granted to inventors to protect their inventions. In exchange for disclosing the invention to the public, the inventor has the right to prevent others from commercializing the invention for a limited period in a specific geographical area. Through disclosure by publication, patents actually reduce secrecy in scientific research. The research exemption provision, moreover, allows experimentation on a patented invention without infringement.

Several hundred European patents covering biotechnological materials, whether nucleotide sequences, proteins, cell lines, antibodies or transgenic organisms, and the processes involved in their production, have been granted by European patent offices over the past fifteen years.
These materials and processes are not automatically patentable simply because they are novel. Unlike scientific discoveries and mathematical equations, patentable inventions must have an "inventive step" and be industrially applicable. It is simply not true that a company has only to make sure of a "microbiological process" to obtain patents. Current European patent law expressly excludes biological materials derived from "essentially microbiological processes".

Nor does the directive take further the question of claim scope. The Biocyte patent has been examined by the European Patent Office according to its patenting criteria. For those who consider this to be the wrong decision, there are established mechanisms to challenge such patents. In general, the scope of biotechnology patents has been getting narrower in Europe. This is a natural consequence of the evolving case law that surrounds biotechnology patents.

It is the responsibility of companies to develop, test and market new drugs and diagnostics. Without the protection offered by patents, they will not make costly and often high-risk investments in new genetic technologies. Although medical charities have raised millions for research to discover the causes of genetic disease, they cannot possibly fund the development of new treatments. Nor should they. Patient support groups are demanding that the benefits of increased scientific understanding are translated into effective diagnostics and treatments quickly, safely and efficiently. The harmonizing proposals within the directive will be an important element in meeting these entirely legitimate concerns. The only alternative to patent protection is secrecy, which will impede research and encourage research duplication.

Alastair Kent

(President, European Alliance

of Genetic Support Groups)

Genetics Interest Group,

Farringdon Point,

29-35 Farringdon Road,

London EC1M 3JB, UK

Nick Scott-Ram

(Chairman, Intellectual Property Advisory

Committee, Bioindustry Association)

British Biotech Pharmaceuticals Ltd,

Watlington Road,

Oxford OX4 5LY, UK

Sandy Thomas*

Science Policy Research Unit,

University of Sussex,

Falmer, Brighton BN1 9RT, UK

*To whom correspondence should be addressed.

\section{Patronomy pioneers}

Sir - Thomas Brooks recently reported on the remarkable case of the newly discovered bird Vireo masteri, whose name has been auctioned by BirdLife International (Nature $385,574 ; 1997)$. He welcomed this and proposed patronomy as a general strategy for worldwide taxonomy. The Zoologische Staatssammlung München (ZSM) has been doing this for more than a year.

The discovery of the biosphere, the documentation of fossil or extant organisms, is one of the most pressing needs of our time. But, whereas 'Systematic Agenda 2000' is well known in the United States, the public in Europe, and in Germany in particular, is only now becoming aware of it. After decades of cutbacks, biosystematic institutions will, without help, certainly fail to fulfil the actual requirements. 'Systematic Agenda 2000' needs partnership. The potential partners, of course, want something for their money, and we can offer patronomies as small but eternal monuments.

The ZSM, a public research institution of zoological systematics, does the following: after a donation to our supporting society (DM5,000 for individuals, twice as much for institutions) and the selection of 'his/her' animal, the donor gets a document confirming the patronomy, formal confirmation of the donation (which can be offset against taxes), an original graphic of the animal (a copy is published), and ten reprints of the published paper. Documents and graphics are presented at celebration events twice yearly.

Although the dedication of a species name "just for money" may be disagreeable to some people, I regard this as a matter of necessity, and its introduction overdue. The idea is hardly new. Many classic names of species were dedicated to express thanks and to honour the (financial) support of research projects, and to encourage the patron to continue making donations. Within our project, the scientific author also thanks the donor for support of biosystematic research.

Clearly, there must be rules to prevent misuse of the project. Individual scientists are encouraged, but not obliged, to take part, and both the ZSM and the systematists are free to refuse sponsorship. The statutes of the supporting society, Freunde der Zoologischen Staatssammlung, guarantee the administration of the donations for zoological research, and the money is spent to buy collections or books, to support scientific journeys or to finance urgently needed equipment.

The patronomy project has been running at ZSM for more than a year. Some of the results have been unexpected. Reports in the press and on television are creating rapidly increasing interest among potential donors, and the media have reacted positively and with enthusiasm. Through these reports, we have also been able to increase public understanding of the problems of biosystematics and biodiversity research. In my view, increasing public awareness is a prerequisite to having a voice in politics. The donors (13 so far) are members of the general public who usually want to dedicate an animal to a loved person. Conventional dedications ("honoris causa') should not, of course, be replaced but supplemented by the project.

The first volume of papers of the project, 'Patronomies', has been published (Spixiana, Supplement 22) and a second series will appear in late autumn.

Gerhard Haszprunar

Zoologische Staatssammlung München,

Münchhausenstrasse 21,

D-81247 München, Germany

e-mail:haszi@zi.biologie.uni-muenchen.de 